\title{
The Importance of Student Leagues on Medical Training in Neurosurgery and Residency Choice
}

\section{A importância das Ligas Acadêmicas no ensino médico e na escolha da residência}

\author{
Daniela Macêdo de Moraes ${ }^{1}$ Vinícius Lopes Braga ${ }^{1}$ Guilherme Salemi Riechelmann ${ }^{1} \quad$ Sérgio Cavalheiro ${ }^{1}$ \\ ${ }^{1}$ Escola Paulista de Medicina - Universidade Federal de São Paulo \\ (EPM-Unifesp), São Paulo, SP, Brazil \\ Arq Bras Neurocir 2018;37:13-18

\begin{abstract}
Address for correspondence Vinícius Lopes Braga, BSc, Escola Paulista de Medicina - Universidade Federal de São Paulo, Rua Napoleão de Barros, 715-Vila Clementina, São Paulo, SP, 04024-002,
\end{abstract} \\ Brazil (e-mail: viniciuslopesbraga@live.com).
}

\begin{abstract}
Keywords

- neurosurgery

- educational assessment

- undergraduate medical education

- student leagues

- neurology

Introduction Neurological and neurosurgical disorders are highly prevalent in Brazil. The initial management is performed by general practitioners, showing the importance of theoretical and practical studies of neurology and neurosurgery during undergraduate medical courses.

Objective Describe the choices of medical specialty by members of a neurosurgery student league and investigate the existence and composition of neurology and/or neurosurgery courses and neuro-leagues in medical schools in Brazil.

Methods We surveyed, in person or through social networks, all medical students who were members of the Neurosurgery Student League of Escola Paulista de Medicina (EPM) from 2007 to 2015 on the completion of their course and residency chosen. An online form was also submitted to all the medical schools registered with the Federal Council of Medicine (Conselho Federal de Medicina [CFM])

Results and Discussion Fifty-seven medical graduates had participated in the Neurosurgery Student League of EPM. Out of these, 45 have completed their undergraduate courses; 6 have undergone neurosurgery and 5 neurology. We obtained responses from 128 out of the 173 medical schools affiliated with the CFM. A total of $91 \%$ of the schools responded that they have a structured neurology course. These courses are divided as into: 32 exclusively theoretical, with 12 addressing neurosurgery and 84 are theoretical-practical, with 51 addressing neurosurgery. Structured neurosurgery courses were only present in $19 \%$ of the faculties, half of which are theoretical only. Neurosciences leagues were present in $66 \%$ of the universities.

Conclusions It was noted that neurology and neurosurgery student leagues in $66 \%$ of the medical schools in Brazil is, many times, used to supplement theoretical-practical content that should have been addressed at undergraduate level. Unfortunately, only $9.5 \%$ of the medical schools include a theoretical-practical neurosurgery course in their curriculum, a fact that is concerning due to the high prevalence of neurologic diseases in the Brazilian population.
\end{abstract}

received

December 4, 2017

accepted

January 17, 2018

published online

April 5, 2018
DOI https://doi.org/

10.1055/s-0038-1641579.

ISSN 0103-5355.
Copyright $(2018$ by Thieme Revinter

Publicações Ltda, Rio de Janeiro, Brazil
License terms

(c) (i) $\ominus$ (\$) 


\begin{abstract}
Resumo
Palavras-chave

- neurocirurgia

- avaliação educacional

- curso de graduação em medicina

- ligas acadêmicas estudantis

- neurologia

Introdução Distúrbios neurológicos e neurocirúrgicos são altamente prevalentes no Brasil. O atendimento inicial é realizado por médicos generalistas, o que demonstra a importância dos estudos práticos e teóricos em neurologia e neurocirurgia nos cursos de graduação em medicina.

Objetivos Descrever a escolha da especialidade médica dos formandos da Liga Acadêmica de Neurocirurgia da Escola Paulista de Medicina (LNC-EPM) e mapear a composição dos cursos de neurologia e/ou neurocirurgia e a presença de ligas acadêmicas dessas disciplinas nas escolas médicas do Brasil.

Métodos Levantamento pessoal ou por rede social com todos os membros da liga de neurocirurgia da EPM de 2007 a 2015 quanto a conclusão do curso e a residência escolhida. Envio de um formulário online para todas as escolas médicas cadastradas no Conselho Federal de Medicina (CFM).

Resultados e Discussão Cinquenta e sete graduandos de medicina já participaram da LNC-EPM, sendo que 45 já concluíram a graduação, 6 fizeram neurocirurgia e 5 neurologia. Conseguimos respostas de 128 das 173 escolas médicas cadastradas no CFM. Um total de $91 \%$ das escolas respondeu que possuem curso de neurologia estruturado. Esses cursos dividem-se em: 32 exclusivamente teóricos, com 12 abordando a neurocirurgia; 84 teórico-práticos, com 51 abordando a neurocirurgia. Apenas $19 \%$ das faculdades apresentam curso próprio estruturado de neurocirurgia, sendo que metade destes é apenas teórico. Um total de $66 \%$ das universidades tem liga acadêmica das disciplinas citadas.

Conclusão Nota-se que a presença de ligas acadêmicas de neurologia e neurocirurgia em $66 \%$ das escolas médicas brasileiras é, muitas vezes, usada para suprir conhecimento teórico-prático que deveria ser abordado na graduação. Infelizmente, apenas 9,5\% das escolas tem curso teórico-prático próprio de neurocirurgia na grade curricular, um fato que é preocupante devido à alta prevalência das doenças neurológicas na população.
\end{abstract}

\section{Introduction}

In the National Curricular Guidelines for Undergraduate Medical Courses, the Federal Council of Medicine (Conselho Federal de Medicina[CFM, in the Portuguese acronym]) determines that the undergraduate medical courses aim at training general practitioners capable of acting at different levels of health care, with an emphasis on primary and secondary care. It also determines that a mandatory competency of graduate professionals is the ability of acknowledging their limitations and adequately referring patients that are beyond their generalist training. ${ }^{1}$ Furthermore, one of the principles guiding the Unified Health System (Sistema Único de Saúde [SUS, in the Portuguese acronym]) is hierarchization, which is in agreement with the organization of services in increasing levels of complexity. Adequate referral plays a fundamental role in following this principle. ${ }^{2}$

Neurologists and neurosurgeons are frequently considered "superspecialists," acting mainly at the tertiary care level. According to this misconception, during undergraduate medical courses, these specialties should focus on themes with higher prevalence on the daily practice of general practitioners. However, their coverage in medical courses is small when compared with their epidemiological relevance. ${ }^{3,4}$
The analysis of data obtained from the Computer Science Department of the Unified Health System (Departamento de Informática do Sistema Único de Saúde [DATASUS, in the Portuguese acronym] $)^{3}$ showed that neurological and neurosurgical disorders are highly prevalent in Brazil, with a highlight for traumatic brain injury (TBI). Traumatic brain injury was responsible for more than 100,000 hospitalizations in Brazil over a 1-year period (from July 2014 to June 2015), 24,000 of which took place in the state of São Paulo. In other words, almost 300 patients with neurological disorders are treated per day. These patients require, at least, a complete initial evaluation so that appropriate action can be taken, and possible immediate referral. This initial consultation is not performed by neurologists or neurosurgeons, but by general practitioners and emergency doctors at emergency rooms (ER) or mobile care units. This shows the importance of theoretical and practical studies of neurology and neurosurgery during undergraduate medical courses.

Student leagues are non-profit scientific civil associations managed by students under teacher guidance, ${ }^{5}$ based in the teaching institutions with which they are affiliated. Their goal is to supplement the studies of specific areas of medicine. ${ }^{3,4}$ They are structured in accordance with the triad 
teaching, research and extension, and provide their members with educational, scientific, cultural and social activities.

In the present study, we aimed at describing the choice of medical specialty by members of the Neurosurgery Student League of Escola Paulista de Medicina - Universidade Federal de São Paulo (EPM/UNIFESP, in the Portuguese acronym), beginning from the implementation of an attendance check system, in 2007. In addition, we investigated the existence and composition of neurology and/or neurosurgery courses and student leagues in medical schools in Brazil, which has not been studied previously. Combining the two parts of the study, we tried to understand the real role and ramifications of participating in student neurosurgery leagues, with a focus on understanding whether student neurosurgery leagues truly influence the choice of medical specialty, or only aim at filling a gap due to lack of neurosurgery courses.

\section{Material and Methods}

We surveyed all medical students who were effective members of the Student League of Neurosurgery of EPM/UNIFESP (founded in 2002) between 2007 and 2015. The survey was performed by consulting the minute book of the league, used for attendance check. Because the records between 2002 and 2007 are incomplete, we chose to analyze the data beginning in 2007, when the systematic weekly record of activities on the minute book began.

After obtaining the full names of the members of the Neurosurgery Student League of EPM/UNIFESP, we looked for their current stage of medical training: graduation, residency, medical specialist, or graduation without beginning of residency. For students attending or that had concluded medical residency, we surveyed their chosen specialty through search on social networks or personal contact. At UNIFESP, there are two other student leagues related to neurology: the Student League of Neurology, and the Neurological Emergencies Student League, recently created in 2015. The present study, therefore, did not intend to analyze the influence of student leagues on the choice of neurology residencies, but only on neurosurgery residencies.

On the second stage of the study, we evaluated the presence and composition (theoretical and/or practical) of neurosurgery and neurology courses, and of student neurosurgery and neurology leagues, in faculties of medicine in Brazil. We initially tabulated all Brazilian medical schools registered with the $\mathrm{CFM}^{4,5}$ in February 2015 and contacted the university secretary offices using a standard email, explaining who was responsible for the study and its aims, and requesting them to fill out a simple online questionnaire (-Fig. 1).

We waited 1 month for the reply of the university secretary offices. We then began directly contacting the students of the faculties of medicine that did not reply to the email. The students were contacted through social networks and were sent the same questionnaire (-Fig. 1). At first, we prioritized contact with presidents and members of the neurology and neurosurgery student leagues of each university (or group of universities, when the student league was affiliated with more than one). When no response could be obtained from this group, we contacted the remaining medical students, prioritizing those who were already attending internship ( $5^{\text {th }}$ and $6^{\text {th }}$ years), and therefore, had a more comprehensive knowledge of the composition of the medical course of their faculty. We gave the students the possibility of indicating another student, if they did not feel able to answer the questionnaire.

It was considered a definitive response to the questionnaire, by order of importance: response by the university secretary office; response of at least one president/member of the neurology or neurosurgery student league; response by at least two students who were not members of a student league, with consultation of a third student if there was divergence in the answers to the questionnaire.

\section{Results}

\section{Epidemiological Evaluation of the Neurosurgery Student League of EPM-UNIFESP}

Between 2007 and 2015, the Neurosurgery Student League of EPM/UNIFESP had a total of 88 effective members, participating on the league for at least 1 year, of which 57 were medical students and 31 were nursing students.

The student contacts through social networks and/or email revealed that, of the 57 members of the Neurosurgery Student League of EPM/UNIFESP, 45 (79\%) had graduated and were attending, or had already concluded, the medical residency. No student within our sample opted for not undergoing medical specialization following graduation. Of the 45 graduated doctors, 6 (13\%) attended or were attending neurosurgery residencies. The medical residency specialties selected by former members of the Neurosurgery Student League of EPM/UNIFESP are presented on - Fig. 2.

\section{Analysis of the Responses to the Questionnaire}

A total of 173 medical schools in Brazil were registered with the CFM in February 2015. ${ }^{5}$ The initial effort of sending the questionnaire via email to all the university secretary offices yielded only two responses after a 1 month wait.

Therefore, we began an active search for presidents and/or members of neurology and neurosurgery student leagues, and undergraduate medical students (prioritizing those already attending internship), according to the method adopted. During this stage, which lasted 2 months, we obtained responses from more than 140 medical schools in the country, with a total $82 \%$ of the sample population answering the questionnaire. Of the 142 questionnaires filled, 14 were excluded due to inconsistent answers, resulting on a final number of 128 medical schools (that is, $74 \%$ of the total faculties of medicine in Brazil).

The answers to the questions regarding presence and distribution of neurology and neurosurgery courses revealed the existence of structured neurology courses on $91 \%$ of the medical schools (116). Of these, 32 were only theoretical, of which 12 covered neurosurgery, and 84 were both theoretical and practical, of which 51 covered neurosurgery (-Fig. 3). 
16 The Importance of Student Leagues in Neurosurgery and Residency Choice Moraes et al.

Institution Name*

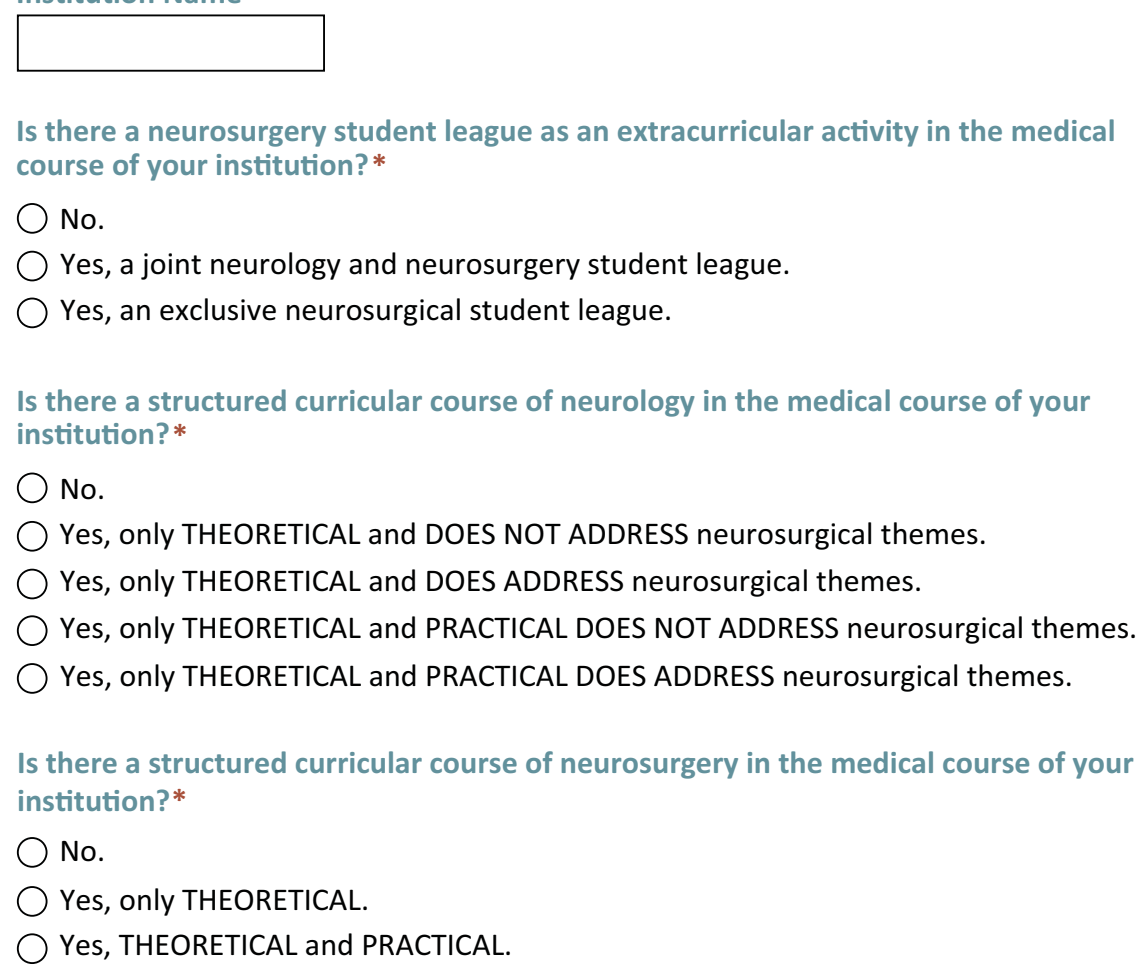

Fig. 1 Questionnaire sent to university secretary offices and medical students.

Structured neurosurgery courses were only present in $19 \%$ of the faculties (24), of which half were only theoretical, and the other half was both theoretical and practical. In total, neurosurgery courses (theoretical or theoretical and practical), either alone or combined with neurology, were only present in medical courses in $68 \%$ of the faculties (87). For the remaining 41 medical schools, if the students depended only on the subjects covered in the undergraduate courses, they would leave without any knowledge of neurosurgery.

Student leagues of neurosurgery or neurology, combined or alone, were present in $66 \%$ of the universities (85). Of these, $81 \%$ (69) were combined neurology and neurosurgery

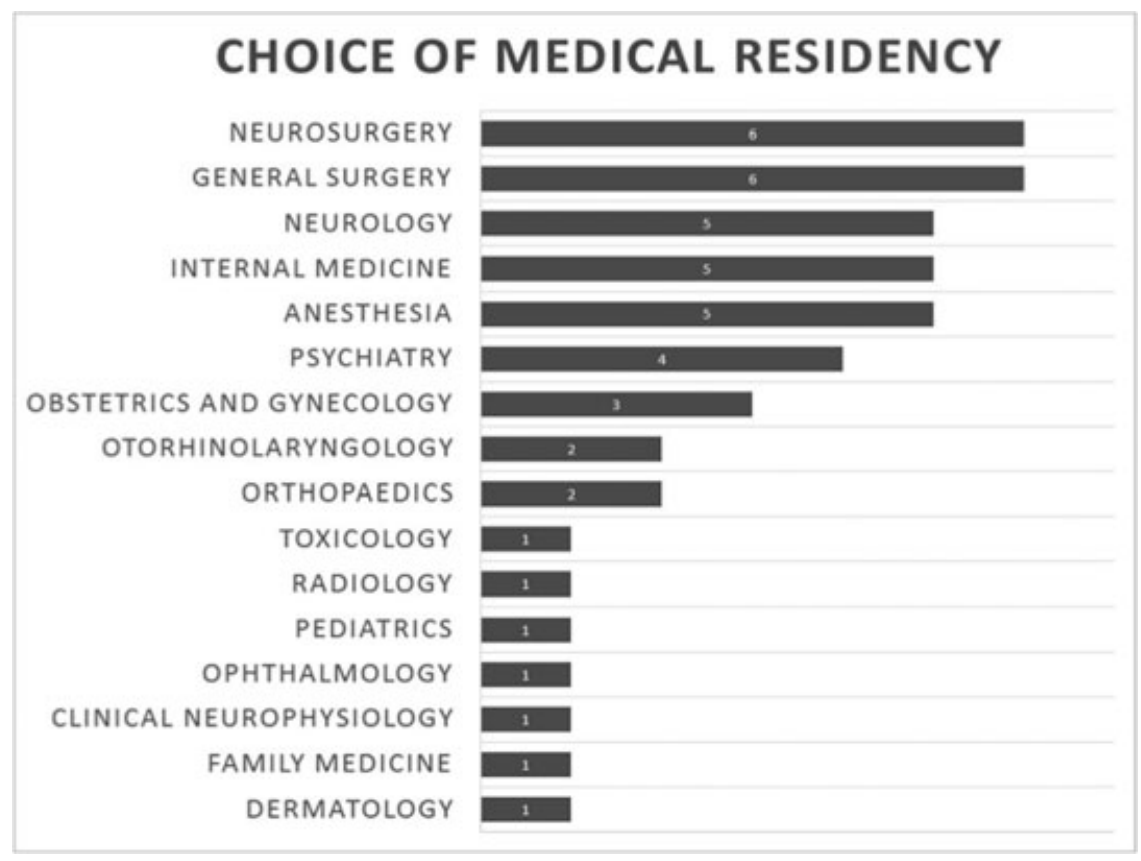

Fig. 2 List of residencies chosen by members of the Neurosurgery Student League at the EMP/UNIFESP. 


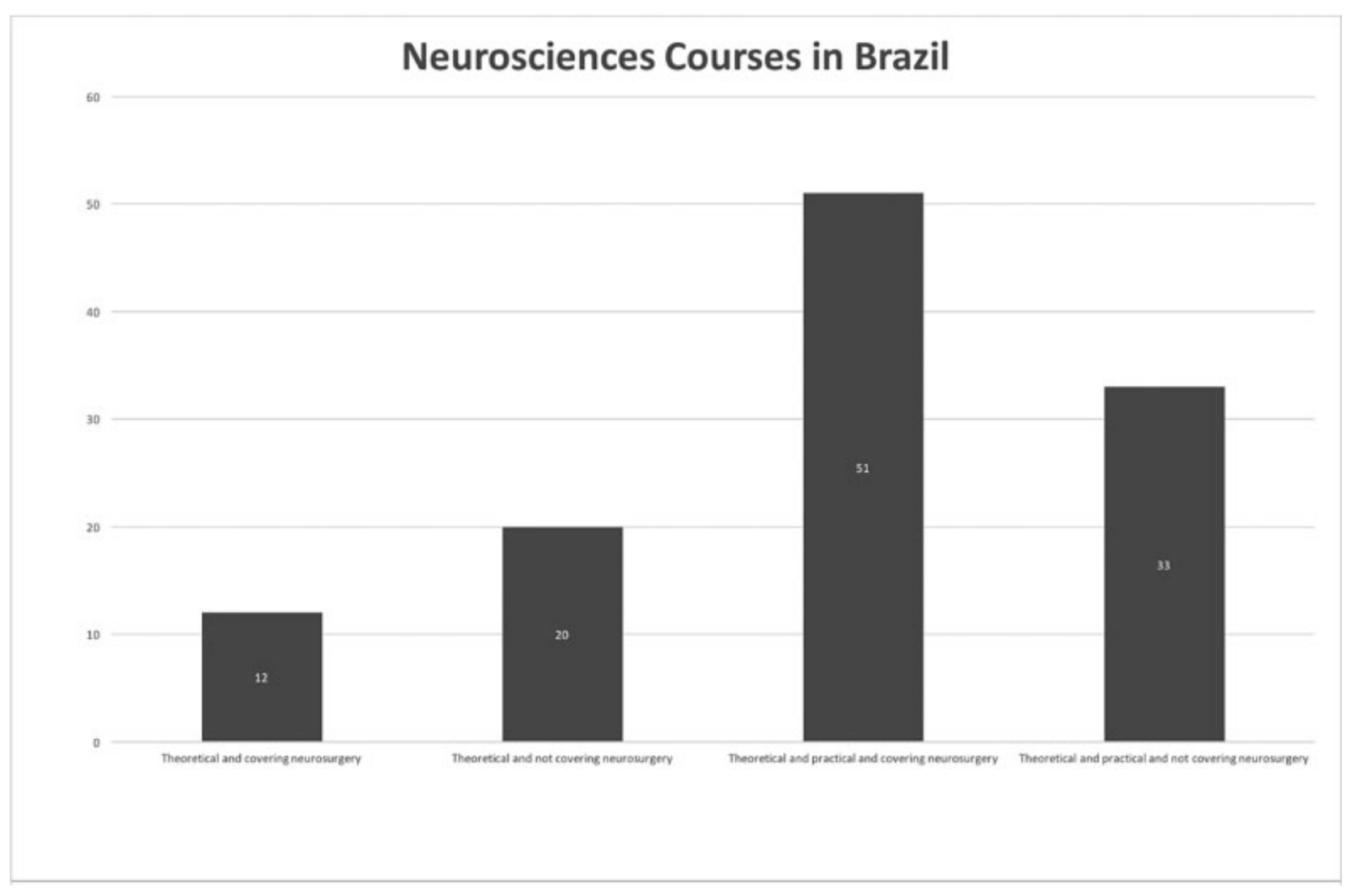

Fig. 3 Structure of neurology courses in medical schools.

leagues, and only 34\% (19) were exclusive neurosurgery leagues.

A separate data analysis revealed that $50 \%$ of the medical schools in Brazil do not possess a neurosurgery program, out of which $44 \%$ offers no practical course and $6 \%$ offers no theoretical or practical course.

\section{Discussion}

Student leagues are associations organized by university students under teacher guidance, with the aim of studying a given subject, ${ }^{6}$ in accordance with the triad teaching, research and extension. ${ }^{7,8}$ Their activities are extracurricular, in order not to compromise the curricular activities of the medical course and aim at supplementing or introducing the apprenticeship of a given subject. However, it is questioned whether these activities are an early superspecialization of undergraduate medical students, who should be focused on learning general medicine, and whether Student Leagues influence future choices of medical specialties. ${ }^{9}$

The Neurosurgery Student League at EPM-UNIFESP provides weekly theoretical classes ( 2 hours long), a monthly discussion of a clinical case (2 hours long), and practical activities, with members participating in monthly 12-hour shifts at the neurosurgery service of the Hospital de São Paulo, accompanying residents, heads of service and teachers. League members are also encouraged to participate and help organizing neurosurgery congresses and student league meetings. In addition, they are invited and encouraged to perform scientific research in neurosurgery. Finally, the extension activities include participation in community health work.

The survey of student members of the Neurosurgery Student League at EPM-UNIFESP during the period when weekly records of activities were kept (2007 to 2015) revealed that there were 57 active members, 45 of whom were already attending or had concluded residency. Of these, only $13 \%$ chose neurosurgery as specialty. This does not allow us to conclude that participating in neurosurgery student leagues determines or even predisposes students to choose this specialty, due to cause and effect bias, and the fact that participating on a given student league, in addition to overcoming undergraduate course shortcomings, meets the student interests and future projects.

Our study did not allow us to evaluate whether student enrollment on neurology and neurosurgery student leagues affected the choice of neurosurgery as specialty, or if both the enrollment and choice of specialty were due to a prior interest on neurosurgery. In addition, both factors- prior interest and student league participation- often concomitantly affect the student choice.

Furthermore, according to the Brazilian Society of Neurosurgery, there are $\sim 2,000$ neurosurgeons in Brazil out of a total of almost 400,000 medical doctors (CFM), that is, only $0.5 \%$ of medical doctors pursue a career in neurosurgery, showing that this market is not yet saturated with professionals. 
Given the massive presence of neurology and neurosurgery student leagues, present in $66 \%$ of the investigated universities, the hypothesis can be advanced that their existence is due to a gap in including these contents in the academic curricula of undergraduate medical courses. Only $19 \%$ of the faculties of medicine evaluated in our study include a neurosurgery program in their undergraduate course, and even fewer possess a theoretical-practical neurosurgery course (9.5\%). The National Curricular Guidelines for Undergraduate Courses in Medicine do not specify mandatory neurology and neurosurgery structured courses in undergraduate medical courses, which disagrees with the high prevalence of neurological and neurosurgical diseases encountered on a daily basis by general practitioners and emergency doctors.

\section{Conclusion}

The present study showed that $13 \%$ of the effective members of the Neurosurgery Student League at EPM/UNIFESP chose neurosurgery as a specialty. In addition, we observed that the student neurology and neurosurgery leagues, present in 66\% of Brazilian medical schools, are often used to supply theoretical-practical knowledge that should be covered in the undergraduate course. However, unfortunately only $9.5 \%$ of medical schools include a theoreticalpractical neurosurgery course in their curriculum. This is worrisome, since neurosurgical diseases have a high prevalence within the epidemiological landscape of Brazil, and therefore, neurosurgery should be taught at all medical schools. In schools already teaching neurosurgery, the workload should be sufficient to allow learning about these diseases.

\section{Sources of Founding}

The authors report no external funding source for this study.

\section{Conflicts of Interest}

The authors declare that there is no conflict of interest regarding the publication of this article.

\section{References}

1 Federal Council of Medicine. National Curricular Guidelines for Undergraduate Medical Courses (2014). http://portal.cfm.org.br/ensinomedico/Diretrizes_Curriculares.pdf, Accessed in 12 October 2015

2 Unified Health System (Sistema Único de Saúde - SUS) - Health Services - Brazil. Ministry of Health. Strategic Planning Department (2000)

3 Queiroz SJ, Andrade M, Casas AL, Santos GM, Chiochetti NB. Ligas Acadêmicas e Currículo Médico: relações e relato de experiência. Fragmentos de Cultura 2015;25(01):47-55

4 Queiroz SJ, Azevedo RL, Lima KP, Lemes MM, Andrade M. A importância das ligas acadêmicas na formação profissional e promoção de saúde. Fragmentos de Cultura 2014;24:73-78

5 Conselho Federal de Medicina. Lista de escolas médicas no Brasil. https://portal.cfm.org.br/index.php?option=com_escolas_ medicas\&Itemid $=49$

6 Costa AP, Afonso CL, Demuner JMM, Moraes JM, Pires WC. A importância da Liga Acadêmica de Queimaduras. Rev Bras Queimaduras 2009;8(03):101-105

7 Pego-Fernandes PM, Mariani AW. O ensino médico além da graduação: ligas acadêmicas. Diagn Tratamento 2011;16(02):50-51

8 Morbidade hospitalar do SUS - traumatismo intracraniano. tabnet.datasus.gov.br, [in Epidemiológicas e Morbidade] accessed in 11 October 2015

9 Rosa SC, Silva VG, Beltrame DP, et al. Retrospectiva dos 10 anos da Liga de Cirurgia Cardiovascular da Universidade Federal do Triângulo Mineiro. Liph Science 2015;2(03):23-36 